\title{
HOSPITAL COLÔNIA DE BARBACENA: UM PASSADO QUE INSISTE EM SE REPETIR
}

\author{
RONALDO MANZI FILHO ${ }^{1}$
}

\begin{abstract}
RESUMO: primeiramente, esse texto busca trazer à tona uma barbárie acontecida no Brasil há poucos anos: o que aconteceu em "O hospital colônia de Barbacena". Podemos hoje ter acesso ao ocorrido devido a alguns relatos, como da pesquisa realizada pela jornalista Daniela Arbex. Com esse material em mãos, é possível analisar o que se passava nesse "hospital" à luz do acontecimento Auschwitz. A proposta desse artigo é mostrar que ainda ressoa a desumanização ocorrida em Auschwitz na atualidade (de forma legal e sob os olhos da sociedade), tal como em Barbacena. Minha proposta é analisar esse fato a partir do autoritarismo brasileiro.
\end{abstract}

PALAVRAS-CHAVE: Hospital Barbacena; Auschwitz; desumanização; eugenização; autoritarismo brasileiro.

\begin{abstract}
Brazil a few years ago: what happened in "Hospital colônia de Barbacena". We can now access the event due to some reports, such as with the research conducted by the reporter Daniela Arbex. With this material in hands, it is possible to analyze what has happened in this "hospital" in the light of Auschwitz event. The proposal of this article is to show that the dehumanization that occurred in Auschwitz still reverberates nowadays (in a legal way and in the eyes of society), as in Barbacena. My proposal is to analyze this fact from Brazilian authoritarianism.
\end{abstract}

KEYWORDS: Hospital Barbacena; Auschwitz; dehumanization; eugenization; Brazilian authoritarianism.

\begin{abstract}
Quando o superintendente do serviço de psiquiatria da Fundação Educacional de Assistência Psiquiátrica, Ronaldo Simões Coelho, pisou no terreno do Hospital de Neuropsiquiatria Infantil, localizado no município de Oliveira, no oeste do Estado, tomou um susto. Logo ao chegar ao hospital do Estado, em 1971, avistou um menino 'crucifixado'. Apesar do sol inclemente, o garoto, que aparentava idade inferior a dez anos, estava deitado no chão, com os braços abertos e amarrados e o rosto queimado pela exposição ao calor de quase trinta graus. Voltou-se para a freira [sic] responsável pelo setor, esperando alguma explicação: - Por que esse menino está amarrado nesse solão? - Se soltar, ele arranca os olhos das outras crianças. Tem mania - respondeu a mulher, com naturalidade. - E quantos olhos ele já arrancou? - Nenhum - disse a religiosa (ARBEX, 2013, p. 87).
\end{abstract}

\footnotetext{
${ }^{1}$ Doutor em Filosofia pela Universidade de São Paulo (USP) e pela Radboud Universiteit Nijmegen (RUN, Holanda) em co-tutela. Formado em psicanálise pelo Centro de Estudos Psicanalíticos (CEP). É membro da International Society of Psychoanalysis and Philosophy (ISPP). E-mail: manzifilho@hotmail.com.
} 
Esse trecho acima certamente parece uma piada ou uma peça cômica de mal gosto. Mas trata-se de uma descrição "comum" do que acontecia nos "hospitais" brasileiros em menos de quarenta anos atrás.

O famoso psiquiatra Franco Basaglia, que promoveu em seu país uma reforma no sistema de saúde mental italiano (conhecida como Lei Basaglia), visitou um dia o Hospital Colônia de Barbacena (fundado em 12 de outubro de 1903 e desativado na década de 1980). Seu encontro com a realidade desse hospital ficou marcado por um longo silêncio de Basaglia ao deixar o hospital até invocar uma coletiva com a impressa para anunciar o que ele viu. Ele descreveu seu contato com o tal hospital nesses termos: "estive hoje num campo de concentração nazista. Em lugar nenhum do mundo, presenciei uma tragédia como esta" (BASAGLIA in ARBEX, 2013, p. 207). O que, exatamente, Basaglia presenciou? O que o levou a comparar um hospital (ou suposto hospital) com um dos acontecimentos mais trágicos da história da humanidade? Teria se reproduzido no Brasil a barbárie nazista?

Em 2013, a jornalista Daniela Arbex publica um livro com vários testemunhos do que ocorreu em Barbacena. Ela nomeou seu livro Holocausto brasileiro - Genocídio: 60 mil mortos no maior hospício do Brasil ${ }^{2}$. Já nas primeiras páginas, ela assim descreve um outro caso "comum" de um dia de um dos internos:

\begin{abstract}
Sônia cresceu sozinha no hospital. Foi vítima de todos os tipos de violação. Sofreu agressão física, tomava choques diários, ficou trancada em cela úmida sem um único cobertor para se aquecer e tomou as famosas injeções de 'entorta', que causavam impregnação no organismo e faziam a boca encher de cuspe. Deixada sem água, muitas vezes, ela bebia a própria urina para matar a sede. Tomava banho de mergulho na banheira com fezes, uma espécie de castigo imposto a pessoas que, como Sônia, não se enquadravam às regras. Por diversas vezes, teve sangue retirado sem o seu consentimento por vampiros humanos que enchiam recipientes de vidros, a fim de aplica-lo em organismos mais debilitados que o dela, principalmente nos pacientes que passavam pela lobotomia. A intervenção cirúrgica no cérebro para seccionar as vias que ligam os lobos frontais ao tálamo era recorrente no Colônia. Embora tenha sido considerada uma técnica bárbara da psicocirurgia, a lobotomia ainda é realizada no país [escrito em 2013] (ARBEX, 2013, p. 51).
\end{abstract}

Talvez a barbaridade da cena descrita seja a percepção de que esse era um dia "comum" no cotidiano desse lugar. E, o pior, apesar de não estarmos falando de Auschwitz, não é difícil reconhecer as mesmas palavras ao ler É isso um homem de Primo Levi ou de qualquer outro

\footnotetext{
${ }^{2}$ Não utilizo o termo "holocausto" que a jornalista emprega. Isso porque acompanho Giorgio Agamben quando esse demonstra como esse termo tem um sentido de "sacrifício supremo, no marco de uma entrega total a causas sagradas e superiores" (AGAMBEN, 2008, p. 39). Ou seja, cotidianamente utilizamos de forma errônea o termo holocausto. Daí porque Agamben afirma que: "no caso do termo 'holocausto', estabelecer uma vinculação, mesmo distante, entre Auschwitz e o olah bíblico, e entre a morte nas câmaras de gás e a 'entrega total a causas sagradas e superiores' não pode deixar de soar como uma zombaria. $\mathrm{O}$ termo não só supõe uma inaceitável equiparação entre fornos crematórios e altares, mas acolhe uma herança semântica que desde o início traz uma conotação antijudaica. Por isso, nunca faremos uso desse termo. Quem continua a fazê-lo, demonstra ignorância ou insensibilidade (ou uma e outra coisa ao mesmo tempo)" (AGAMBEN, 2008, p. 40).
} 
sobrevivente de Auschwitz. Não é difícil associarmos o caso acima com passagens das descrições de Levi:

nossa condição de prisioneiros sem prazo, condenados sem processo a uma existência de fome, surras, frio, cansaço e, no fim, à morte por gás como os ratos, era em si tão injusta que, pensávamos, teria sido mais do que suficiente para desqualificar o nazifascismo aos olhos de todos, para demonstrar sua iniquidade, assim como os teoremas demonstram a verdade da geometria: aliás, para fazê-lo desaparecer por gerações, talvez para sempre (LEVI, 2016, p. 53).

É assim que, num texto de 1974, pasmo, mas de forma "profética", infelizmente, Primo Levi escreve um pequeno texto para a Corriere dela Sera intitulado "Um passado que acreditávamos não mais voltar". Trata-se de um texto 29 anos após a libertação dos campos de concentração nazista. A questão de Levi é que ele temia que a experiência de Auschwitz se repetisse de algum modo. Ou seja, não se trataria simplesmente de uma péssima memória do que os homens são capazes de fazer, mas de uma experiência que ressoa e se manifesta em outros lugares, de forma disfarçada e, pior, sob o regimento da lei.

Não se trata de uma percepção isolada. Em um prefácio à obra de L. Poliavov denominada Auschwitz, por exemplo, de 1968, Levi diz que “Auschwitz está fora de nós, mas em torno de nós, está no ar. A peste acabou, mas a infecção grassa: seria tolo negar" (LEVI, 2016, p. 47).

Em 1973, num outro prefácio, agora à sua própria obra É isto um homem?, e direcionado aos jovens, ele lembra dessa realidade terrível da fala de Brecht: "o útero que pariu esse monstro ainda é fértil” (BRECHT apud LEVI, 2016, p. 51). É como se Auschwitz estivesse presente de forma "disfarçada".

Naquele texto de 1974, Levi faz uma denúncia: “(...) e hoje, em quase todos os países, existem prisões, instituições para menores, hospitais, onde - assim como em Auschwitz - o ser humano frequentemente perde nome e rosto, dignidade e esperança" (LEVI, 2016, p. 55). Naquele prefácio à sua obra, Levi nos lembra, em um dado momento, do que acontece nos hospitais psiquiátricos no Brasil ao menos na década de 1970. Nesse momento, ele diz:

\footnotetext{
em quase todos os países, existem prisões, instituições para menores, hospitais psiquiátricos onde, como em Auschwitz, o ser humano perde nome e rosto, dignidade e esperança. Acima de tudo, o fascismo não morreu: consolidado em alguns países, esperando cautelosamente a desforra em outros, não parou de prometer ao mundo uma Ordem Nova (LEVI, 2016, p. 50-51).
}

A ideia é que ainda na década de 1970 poderíamos comparar algumas instituições que eram gestadas legalmente pelo governo com o que aconteceu em Auschwitz - lugares em que o ser humano "perde seu nome e rosto, dignidade e esperança". 
Claro que, em números, nada é comparável aos campos de concentração nazistas - e se espera que algo jamais seja comparável àquilo numericamente (ao menos). Mas, em proporções menores, a ideia de campo de concentração parece se estender na contemporaneidade de forma presente, atuante e legal. Eis o caso de Barbacena.

\title{
Qual seria a lógica do internamento?
}

Ao ler a descrição do que se passou no Hospital Colônia, o mais difícil de entender é a lógica que se estabelece para que se interne uma pessoa. Eis um exemplo:

\begin{abstract}
aos quinze anos, Conceição foi mandada para o hospital, porque decidiu reivindicar do pai a mesma remuneração paga aos filhos machos. Embora trabalhasse como os irmãos na fazenda de Dores do Indaiá, município pouco povoado do centro-oeste das Gerais [Minas Gerais], a filha do fazendeiro não desfrutava dos mesmos direitos. Pela atitude de rebeldia da adolescente, o pai aplicou o castigo. Decidiu colocar Conceição no famigerado 'trem de doido', único no país que fazia viagens sem volta. Em 10 de maio de 1942, ela deu entrada no hospital [aqui deveria ter aspas], de onde nunca mais saiu. Em trinta anos, nunca recebeu visita (ARBEX, 2013, pp. 39-40).
\end{abstract}

Ou seja, esse "hospital" parece abrigar pessoas sem qualquer função terapêutica. Os exemplos que Arbex traz em seu livro são muitos: Maria de Jesus foi internada porque tinha sintoma de tristeza; "[Sônia] Rejeitada aos onze anos por fazer molecagem na rua, em Belo Horizonte, foi despachada para o hospital pela polícia” (ARBEX, 2013, p. 50); Luiz Pereira de Melo: internado por ser tímido! (internado aos 16 anos...); Adelino Ferreira Rodrigues: internado por ter sido mordido por um cachorro! Outro exemplo: "o exílio no hospital foi a forma que o patrão de Virginópolis (MG) encontrou de silenciar a menina que ele havia estuprado no período em que trabalhava em sua casa. Com então cinquenta e quatro anos, ele precisava esconder a gravidez da garota a qualquer custo, nem que, para isso, confiscasse, mais uma vez, a inocência dela" (ARBEX, 2013, p. 145). Eis como um jornalista, segundo Arbex, tentou entender essa lógica:

Hiram passou o dia fazendo entrevistas. Ouviu pessoas que foram internadas apenas porque tinham perdido a carteira e ficado sem os documentos. Outros foram pegas usando maconha e levadas para lá. Constatou, ainda, a falta de critérios médicos para as internações, a ausência de voz dos pacientes e a impotência diante do sistema. Também se comoveu com o fato de os considerados doentes terem sido presos sem terem cometido crime algum. Tentou não julgar. Ao deixar a unidade, sentou-se à máquina de escrever (ARBEX, 2013, p. 213).

A única "lógica" possível que se possa ter entre esses casos insólitos é: exclusão - todos aqueles que são malquistos na sociedade podem, de um dia para outro, serem enviados para Barbacena (é possível excluir tudo o que não se deseja socialmente sob uma forma legal - aos 
olhos do Estado, da polícia, dos políticos, da sociedade, etc.; não só "aos olhos", mas tendo a sua aprovação jurídica). Essa é uma das passagens mais assustadoras do livro de Arbex:

a estimativa é que $70 \%$ dos atendidos não sofressem de doença mental. Apenas eram diferentes ou ameaçavam a ordem pública. Por isso, o Colônia tornou-se destino de desafetos, homossexuais, militantes políticos, mães solteiras, alcoolistas, mendigos, negros, pobres, pessoas sem documentos e todos os tipos de indesejados, inclusive os chamados insanos. A teoria eugenista, que sustentava a ideia de limpeza social, fortalecia o hospital e justificava seus abusos. Livrar a sociedade da escória, desfazendo-se dela, de preferência em local que a vista não pudesse alcançar (ARBEX, 2013, pp. 25-26).

Os presos em Auschwitz, na sua maioria, foram detidos por sua raça, cor, escolha sexual, posição social, crença ideológica, por possuírem deficiência (física e/ou mental); também por serem "criminosos" políticos (ao menos aos olhos dos nazistas) ou criminosos "comuns" - tudo aquilo que poderia alterar o suposto "verdadeiro sangue alemão". No caso de Barbacena, não parece ser muito diferente: todos os que não são desejados na sociedade (ladrões, prostitutas, mulheres que engravidaram de pessoas casadas, mendigos, deficientes físicos e/ou mentais ou alguém que simplesmente desafiou o poder estabelecido etc.) podem ser simplesmente enviados para lá. Sendo assim, literalmente, qualquer um poderia ser enviado ao Colônia, basta que alguém com alguma autoridade (médico, delegado, deputado etc.) autorize a internação, o que confirma a tese de sociólogo(a)s brasileiro(a)s, como Roberto DaMatta (ver, por exemplo, Carnavais, Malandros e Heróis) ou de filósofo(a)s brasileiros, como Marilena Chaui (ver, principalmente, Manifestações ideológicas do autoritarismo brasileiro), que a sociedade brasileira é fundamentalmente hierárquica e autoritária (mesmo sob o suposto regime democrático) $)^{3}$. O Hospital Colônia, sendo assim, é "somente" a expressão mais visível do autoritarismo brasileiro.

Nessa lógica, é-se condenado por uma fala: a partir do momento em que se é nomeado "louco", seja por um médico, um delegado ou uma figura de autoridade qualquer, é-se tratado como tal. Trata-se então do que John Langshaw Austin denomina ato performativo: uma fala

\footnotetext{
${ }^{3}$ Que se veja essa passagem de Chaui: "o Brasil é uma sociedade autoritária, na medida em que não consegue, até o limiar do século XXI, concretizar nem sequer os princípios (velhos, de quase quatro séculos) do liberalismo e do republicanismo. Indistinção entre o público e o privado, incapacidade para tolerar o princípio formal e abstrato da igualdade perante a lei, combate da classe dominante às ideias gerias contidas na Declaração dos Direitos do Homem e do Cidadão (de 1789) e na Declaração dos Direitos Humanos (de 1948), repressão às formas de luta e de organização sociais e populares, discriminação étnica, sexual e de classe; a sociedade brasileira, sob a aparência de fluidez, estrutura-se de modo fortemente hierárquico, e, nela, não só o Estado aparece como fundador do próprio social, mas também as relações sociais se efetuam sob a forma da tutela e do favor (jamais do direito), e a legalidade se constitui como círculo fatal do arbítrio (dos dominantes) à transgressão (dos dominados) e, desta, ao arbítrio (dos dominantes)" (CHAUI, 2013, p. 257).
} 
que instaura uma nova realidade no sujeito ${ }^{4}$. Instaurada essa fala ("é louco", por exemplo), o condenado é enviado a Barbacena. Normalmente, por trem, que ficou conhecido como "trem de loucos" e que foi imortalizado em um conto de Guimarães Rosa (Sorocô, sua mãe, sua filha). Nesse trem, chegavam várias pessoas que desciam e passavam por uma triagem - para se saber em qual dos pavimentos deveria ser direcionado cada um. Impossível não lembrar de Auschwitz: os recém-chegados eram separados por sexo, idade e características físicas. Por exemplo: se era ou não capaz de trabalhar, ou seja, se teria sua vida "prolongada" pela exploração do trabalho (como construir igrejas que jamais teriam a permissão de entrar) ou se já o deixava definhando desde já. A triagem tinha exatamente as mesmas características que se vê descritas em Auschwitz: passa-se pela entrega dos pertences, inclusive as roupas; os pelos do corpo eram raspados; faz-se algum procedimento estranho de "desinfecção"; muitas vezes, passa-se por uma sessão de eletrochoque para "amansar" a pessoa; é-se examinado por um "médico"; dada uma roupa/uniforme que ficou conhecida como "azulão" (um uniforme que logo era tirado dos internos com a justificativa de lavagem e jamais entregue de volta); e indicado um "caminho". E, como diz Arbex, "daquele momento em diante, elas [as internadas] deixavam de ser filhas, mães, esposas, irmãs" (ARBEX, 2013, p. 28), eram doravante apenas um corpo, um bicho, sem qualquer direito, sem nome, sem uma história qualquer. Desde ali, tem-se a "humanidade confiscada" e deve-se aceitar o "fato" de serem "loucos", levando sessões de eletrochoque, andando nus, bebendo água do esgoto que recorta o instituto, comendo o que encontravam no chão...

O que se sabe de fato é que mais de sessenta mil pessoas morreram nesse hospital. Mas não é isso que faz do Colônia algo único e sim a forma com que as pessoas se transformavam em não humanos, em bichos, em mortos-vivos. Eis porque esse hospital em Barbacena é facilmente associado ao que Giorgio Agamben descreveu sobre o Homo Sacer: uma forma de suspensão da humanidade do homem, tornando-o "fora" do humano e de forma legal. Ao tirar a humanidade do homem, ao animaliza-lo, cria-se uma exceção: o que não era previsto dentro do conjunto "homem". A barbárie acontecida em Barbacena é que a exceção abriu um novo

\footnotetext{
${ }^{4}$ J. Austin, em 1955 (Como fazer coisas com palavras), formaliza uma possibilidade da linguagem: é possível que haja falas que não pretendem ter qualquer relação com estado de coisas, pois elas não dizem nada em relação à suposta verdade ou falsidade da fala. Ao dizer, por exemplo, que "eu aceito" me casar com x ou y; ou que "eu aposto que isso seja mais vantajoso do que x"; que "eu declaro y" etc., nos deparamos com falas que não se relacionam com estados de coisas. Ao mesmo tempo, são falas que modificam estados de coisas. Por exemplo: ao dizer que "eu aceito" me casar com tal pessoa, nada mais será como antes - essa fala modifica um estado de coisas sem ter qualquer referência a um estado de coisas real - não é falsa nem verdadeira (cf. AUSTIN, 1962, p. 5), é a instauração de uma nova realidade.
} 
conjunto que não conhecíamos: esses mortos-vivos que excluímos do convívio social, da polis, por termos achado "conveniente". Uma eugenização - sem meias palavras!

Já é uma barbárie que tal tenha ocorrido. Pior seria, parece-me, nos silenciarmos diante do que aconteceu. Por que não falamos sobre Barbacena?

\title{
Algumas descrições
}

O livro de Daniela Arbex começa com a descrição de uma nova funcionária que acaba de chegar no Colônia. A descrição é sobre a impressão que essa funcionária (Marlene) teve ao avistar o que ela enfrentaria doravante. Chegando no Colônia, ela se depara com um pavilhão e entra. Assim Arbex descreve:

\begin{abstract}
um cheiro insuportável alcançou sua narina. Acostumada com o perfume das rosas do escritório da Brasil Flowers, onde passou por sua única experiência profissional até aquele momento, Marlene foi surpreendida pelo odor fétido, vindo do interior do prédio. Nem tinha se refeito de tamanho mal-estar, quando avistou montes de capim espalhados pelo chão. Junto ao mato havia seres humanos esquálidos. Duzentos e oitentas homens, a maioria nus, rastejavam pelo assoalho branco com tozetos pretos em meio à imundice do esgoto aberto que cruzava todo o pavilhão. Marlene sentiu vontade de vomitar. Não encontrava sentido em tudo aquilo, queria gritar, mas a voz desapareceu da garganta (ARBEX, 2013, pp. 22-23).
\end{abstract}

Que se tente imaginar um local que foi "planejado" (se é que se pode usar esse tipo de verbo no caso) para abrigar 200 pessoas e que, em sua lotação máxima, encontrava-se com 5 mil pessoas; que não havia qualquer possibilidade de higiene; ou de uso de cama (por isso dormiam em capim - uma "façanha" que foi aprovada e disseminado pelo Estado pelos "bons" resultados na economia de espaço e em material dedicado aos detentos: "o modelo do leito chão deu tão certo, que foi recomendado pelo Poder Público para outros hospitais mineiros em 1959" (ARBEX, 2013, p. 26)); ou de alimentação (que foi confundida por um dos médicos que visitou a instituição com ração para porcos); ou qualquer tipo de cuidado (mesmo tendo como denominação ser um "hospital”), quer seja o mínimo possível, como ter uma roupa.

A funcionária deparou-se com homens transformados em bichos, ela mal podia diferenciar se tal corpo estava vivo ou não: “ainda com os pensamentos descoordenados, avistou num canto da ala um cadáver misturado entre os vivos. Observou quando dois homens de jaleco branco embrulharam o morto num lençol, o décimo sexto naquele dia, embora muitos outros agonizassem” (ARBEX, 2013, p. 23).

A funcionária Marlene, que é retratada em uma longa parte do livro, se vê nessa situação, segundo Arbex: "começara a trabalhar num campo de concentração travestido de hospital" (ARBEX, 2013, p. 25) - e diga-se de passagem: um lugar que teve apoio da Igreja Católica desde a sua fundação. Ou seja, um local que tinha o apoio do Estado e da Igreja, assim como o 
silêncio da sociedade, que o viu funcionando por mais de 80 anos e sabendo que todos que iam para lá jamais retornariam de sua sentença de desumanização. É como se a sociedade fosse cúmplice de uma barbárie e usasse do poder do ato performativo (apontar alguém e o declarar "louco") para excluir quem quer que fosse - como se tivéssemos instaurado um decreto de "poder excluir legalmente" o que consideramos inadequado, sob a aprovação da Igreja e do Estado.

Dentro, o humano se desumaniza. E pior, torna-se cúmplice dessa barbárie tal como os nazistas fizeram com os judeus: fizeram com que eles mesmos colaborassem. Por exemplo: nos campos de concentração, como descrevem vários sobreviventes, alguns judeus eram responsáveis na seleção e na execução nas câmeras de gás. Eram judeus que levavam judeus para as câmaras - uma espécie de sadismo que os nazistas realizavam e uma forma de terem "menos culpa" do que estavam realizando. O mesmo se dava em Barbacena, segundo as descrições de Arbex: também os detentos do Colônia seguravam seus companheiros e o amarravam para dar sessões de eletrochoque. Um dos poucos médicos que apareceram por lá testemunha: "a coisa era muito pior do que parece. Havia um total desinteresse pela sorte. Basta dizer que os eletrochoques eram dados indiscriminadamente. Às vezes, a energia elétrica da cidade não era suficiente para aguentar a carga. Muitos morriam, outros sofriam fraturas graves" (ARBEX, 2013, p. 36). Qual é a lógica disto?

Em Barbacena aconteciam coisas que dificilmente poderia ter qualquer justificação. Exemplo: para ser contratado um novo funcionário, eles faziam testes de eletrochoque nos "pacientes". Em quase todos os casos, os "pacientes" morriam. A questão era: você suporta trabalhar aqui? Tem algo de muito sádico em escolher pessoas para esse "treino" sabendo que elas vão morrer.

Outro exemplo inacreditável: "apesar de o café da manhã ser fornecido às 8 horas, três horas antes os pacientes já tinham que estar de pé. Eles seguiam para o pátio de madrugada, inclusive nos dias de chuva" (ARBEX, 2013, p. 47). Por quê? A única "explicação" é que não se trata mais de homens: "ao seguirem pelados para o pátio, os considerados loucos iniciavam o mesmo ritual da madrugada anterior. Em movimentos ritmados, agrupavam-se tão próximos, que formavam uma massa humana. Vagavam juntos, com os braços unidos, para que o movimento e a proximidade ajudassem a aquecer" (ARBEX, 2013, p. 48). Que se veja ainda esse caso:

assim como a interna Celita Maria da Conceição, ela [Sônia] passou as próprias fezes no corpo durante o período em que esteve grávida no hospital. Questionada sobre o ato repugnante, Sônia justificou: - Foi a única maneira que encontrei de ninguém machucar meu neném. Suja deste jeito, nenhum funcionário vai ter coragem de 
encostar a mão em mim. Assim, protejo meu filho que está na barriga (ARBEX, 2013, pp. 51-53).

Cria-se, assim, incrivelmente, um repelente para se defender dos homens. Melhor: os "loucos" criam uma forma de se defenderem dos "sãos".

Mais incrível ainda, quase que insólito, é o comércio dos corpos. O hospital era um "bom negócio", porque os corpos eram vendidos. Eis a fala de uns dos funcionários que "recebia" os corpos em uma Universidade (cúmplice dessa barbárie):

\begin{abstract}
Rapaz, que luta! Essa madrugada uma camioneta de Barbacena chegou lotada de cadáveres. O responsável localizou o diretor da medicina e ofereceu cada corpo por 1 milhão (cerca de R\$ 364 nos dias atuais [2013]). Se a universidade não quisesse, já tinha comprador no Rio de Janeiro. Claro que o diretor não podia perder a oportunidade. Estávamos apenas com seis cadáveres, e o preço estava bom. Além disso, trinta corpos suprem as necessidades do ano inteiro. Com isso, fui tirado da cama e vim para cá. Estou caindo de cansaço e sem ajudante até agora, tendo de formolizar todo esse material [sic] antes de colocar os cadáveres nos tanques (ARBEX, 2013, p. 74).
\end{abstract}

Uma indústria de corpos:

os corpos dos transformados em indigentes foram negociados por cerca de cinquenta cruzeiros cada um. O valor atualizado [2013], corrigido pelo Índice Geral de Preços (IGP - DI) da Fundação Getúlio Vargas, é equivalente a R \$ 200 por peça [sic]. Entre 4 e 19 de novembro de 1970, foram enviados para a Faculdade de Medicina de Valença quarenta e cinco cadáveres negociados por 2.250 cruzeiros o lote. Corrigido pelo IGP - DI, o lote saiu a R \$ 8.338,59. Em uma década, a venda de cadáveres atingiu quase R $\$ 600$ mil, fora o valor faturado com o comércio de ossos e órgãos (ARBEX, 2013, p. 77).

Ou seja, não era natural "somente" conviver com a morte (porque se morria todos os dias nesse hospital e muitas vezes os funcionários só percebiam que havia uma diferença entre em um vivo e um morto não pelo cheiro, nem pela aparência, nem pelas moscas - somente pela rigidez do corpo), mas também era natural fazer dessa barbárie um comércio que nem era voltado à instituição, e sim aos bolsos de alguns dos diretores.

A desumanização é indescritível, apesar de testemunhável. E mais assustador é como os funcionários, principalmente os médicos, lidavam com a situação. Eis um dos casos:

o prontuário do mês de setembro de 1981 indica mais um surto de Sueli. Alegando estar faminta, ela pegou uma pomba no pátio, estraçalhou e comeu na frente de todos, dizendo que era seu único alimento. A cena chocante foi vista por centenas de pessoas, inclusive pelos atendentes, mas ninguém conseguiu enxergar o óbvio: em que a jovem paciente havia se transformado em uma década de internação. Tratada como bicho, ela comportava-se como um. Decididos a conter a agressividade de Sueli, os médicos [sic] reuniram-se. Depois de horas de discussão, apresentaram como sugestão uma medida: arrancar a arcada dentária da paciente (ARBEX, 2013, p. 125). 
Que se tenha cumprido ou não essa sugestão, como isto pode ser considerado uma sugestão médica?

Outros médicos que passavam por lá, não tinham o mesmo critério. Apenas testemunhavam. Um exemplo:

\begin{abstract}
lá, existe um psiquiatra para 400 doentes. Os alimentos são jogados em cochos, e os doidos avançam para comer. O que acontece no Colônia é a desumanidade, a crueldade planejada. No hospício, tira-se o caráter humano de uma pessoa, e ela deixa de ser gente. É permitido andar nu e comer bosta, mas é proibido o protesto qualquer que seja a sua forma. Seria de desejar que o Hospital Colônia morresse de velhice. Nascido por lei, em 16 de agosto de 1900, morreria sem glórias. E, parafraseando Dante, poderia ser escrito sobre o seu túmulo: quem aqui entrou perdeu toda a esperança (ARBEX, 2013, pp. 200-201).
\end{abstract}

O testemunho desse médico é "precioso" por nos dizer que se trata de uma "crueldade planejada". Ou seja, eles sabiam o que estavam fazendo (o Estado, os funcionários e seus cúmplices).

\title{
O hospital colônia como exemplo
}

Nesse ponto, podemos lembrar que Auschwitz é considerado uma exceção, por Agamben, porque nada parecido jamais tinha sido possível imaginar. É como se o que ocorreu em Auschwitz não pudesse participar do conjunto do possível. Assim, ele abre um novo conjunto em que não sabemos ao certo quais são suas novas possibilidades. O Hospital Colônia nos dá uma ideia do que se tornou possível. Assim, o que aconteceu no Colônia não é uma exceção, mas um acontecimento dentro dessa nova lógica que Auschwitz proporcionou. Colônia é um exemplo desse novo conjunto.

Esse novo conjunto aberto por Auschwitz poderia ser caracterizado tal como Hannah Arendt descreveu o processo de Adolf Eichmann em seu julgamento em Jerusalém: doravante temos que levar em conta a banalidade do mal. Eichmann foi julgado principalmente por ter sido o mentor da Solução Final (o extermínio completo dos judeus como solução!). O que é assustador na descrição de Arendt é como os funcionários de um campo de concentração não podem ser rotulados como "monstros", mas como seres humanos normais, banais, burocratas, "que cumprem seu dever". Como insiste Arendt, seria muito confortável simplesmente dizer que Eichmann é um monstro (uma exceção) e que não serve de exemplo para outros casos. O que realmente incomoda nesse caso é que Eichmann é considerado normal. E pior: 
advogados o repetem, em Nuremberg, mil vezes) que esse novo tipo de criminoso, todo hostis humani generis que ele seja, comete crimes em circunstâncias tais que lhe é impossível saber ou sentir que ele fez o mal (ARENDT, 1997, p. 444).

Ou seja, pessoas que têm um "trabalho" no Estado (concursados, no caso do Brasil) e seguem suas ordens: por exemplo, dar eletrochoques diários em pessoas (no caso do Colônia), mesmo sabendo que essas pessoas irão morrer nesse processo (como acontecia diariamente). Afinal, o mal se torna banal... A questão é: como é possível que haja funcionários nesse tipo de instituição? Pessoas que trabalham num campo de concentração e que, cumprido o horário de trabalho, retornam para sua casa, para sua família... e que recebem mensalmente por sua função nessa barbárie. É certo que Arbex mostra como os funcionários se sentiam mal em seus deveres, mas eles os cumpriam e depois testemunharam sobre o que faziam, sem serem condenados, "obviamente", porque estavam cumprindo "ordens" do Estado - que, aliás, fez e faz de tudo para esconder suas barbáries (como nas torturas durante a ditadura militar recente).

Em 1998, Agamben escreve $O$ que resta de Auschwitz e se pergunta se é possível compreender o que aconteceu em Auschwitz. Ou seja, trata-se de algo que está na ordem do compreensível?

Em Auschwitz, tinha-se uma estratégia: ao desumanizar o homem, essa "coisa" se torna matável! É uma estratégia jurídica.. Faz-se, assim, que haja a sociedade dos humanos e aqueles que foram excluídos do mundo humano e, por isso, não podem mais ser defendidos pela lei humana: cria-se uma situação limite que torna "essa coisa" algo não suportável aos olhos humanos ( $c f$. AGAMBEN, 2008, p. 59). É nesse sentido que Auschwitz se tornou uma exceção - algo que ainda não conhecíamos: um lugar que transformou o homem em algo impensável.

Lembremos que Heidegger diz que o homem é um ser-de-possibilidades. Mas Heidegger não previu que pudesse haver a possibilidade desse ser-de-possibilidades se tornar um não-humano. É isso que Agamben denominou vida nua - um homem que perdeu qualquer forma-de-ser e se tornou "simplesmente" vivo, sem forma, sem rosto, sem história: "o mulçulmano é o não-homem que se apresenta obstinadamente como homem, e o humano que é impossível dissociar do inumano" (AGAMBEN, 2008, p. 87).

Não se trata, portanto, de um ser-para-a-morte, como dizia Heidegger, mas de um ser que é transformado vivo em cadáver. Essas palavras de Agamben poderiam ser usadas para descrever também o que ocorreu no Hospital Colônia:

em Auschwitz não se morria: produziam-se cadáveres. Cadáveres sem morte, nãohomens cujo falecimento foi rebaixado a produção em série. É precisamente a degradação da morte que constituiria, segundo uma possível e difundida interpretação, a ofensa específica de Auschwitz, o nome próprio do seu horror (AGAMBEN, 2008, p. 78). 
Em outras palavras, o campo de extermínio não é um lugar em que se mata, mas que torna a pessoa em algo matável.

Agamben nos mostra que "não se pode querer que Auschwitz retorne eternamente, porque, na verdade, nunca deixou de acontecer, já se está repetindo sempre" (AGAMBEN, 2008, p. 106, grifo do autor). Agamben está pensando nessa passagem na memória dos sobreviventes e da nossa história recente. Mas esse "não deixou de acontecer", infelizmente, tem um sentido mais concreto no Brasil: um Hospital que repete/reproduz Auschwitz. Como isso é possível?

\section{O autoritarismo no Brasil}

Como já destacamos, essa lógica de internação segue um ato de exclusão que só é possível dentro de uma sociedade autoritária.

Machado de Assis teria sido um dos primeiros a realmente descrever nossa sociedade ao apontar o paternalismo como característica central dela. Por isso, Roberto Schwarz pode afirmar que se trataria do primeiro romancista brasileiro que teria um feito: escrever um romance realmente com as nossas características enquanto sociedade, "uma forma muito melhor do que nova, original no sentido forte da palavra, em que a originalidade do processo nacional vem a ser a premissa da fantasia romanesca, que vai se tornando exata" (SCHWARZ, 2000, p. 190).

Muitos são os pensadores brasileiros que mostraram a concepção patriarcal/autoritária de nossa sociedade. Pensadores como Sérgio Buarque de Holanda chegam a apontar que esse caráter nacional tem uma raiz entre os espanhóis e portugueses:

a vontade de mandar e a disposição para cumprir ordens são-lles [nos povos ibéricos] igualmente peculiares [além da obediência cega]. As ditaduras e o Santo Ofício parecem constituir formas tão típicas de seu caráter como a inclinação à anarquia e à desordem. Não existe, a seu ver, outra sorte de disciplina perfeitamente concebível, além da que se funde na excessiva centralização do poder e na obediência (HOLANDA, 1995, p. 39).

É por isso que Holanda insiste que a nossa sociedade é patriarcal e autoritária: devido a uma herança histórica da forma em que o Brasil foi colonizado. Não é de estranhar assim que hoje se desponte uma sociedade hierárquica e autoritária, como insistem vários autores.

A lógica de internação que se verifica no Hospital Colônia só é possível nesse tipo de sociedade: em que alguém com autoridade instaura, em um ato performativo, o destino de pessoas sem que haja uma coerência clínica senão a autoridade de poder excluir os malquistos socialmente. 
Talvez a percepção de Roberto DaMatta sobre um dito brasileiro nos deixe mais claro o porquê da relação entre o autoritarismo como condição de possibilidade para que haja algo como o Hospital Colônia. DaMatta escreve Sabe com quem está falando? Um ensaio sobre a distinção entre indivíduo e pessoa no Brasil em 1978, para mostrar como, nos ditos mais cotidianos, nos flagramos autoritários e hierárquicos. Essa expressão "sabe com quem está falando?" está no nosso coração cultural brasileiro ( $c f$. DAMATTA, 1997, p. 182). Trata-se de uma declaração performativa de hierarquia: o frisar que existem posições sociais de senhor/escravo.

Entretanto, apesar dessa expressão ser sistematicamente ouvida, ela é, ao mesmo tempo, velada nas relações sociais, pois, como diz DaMatta, ela é reveladora “(...) do nosso formalismo e da nossa maneira velada (e até hipócrita) de demonstração dos mais violentos preconceitos" (DAMATTA, 1997, p. 182) ${ }^{5}$. Assim, nada é mais hipócrita do que insistir, como se faz a propaganda do Brasil no exterior, que somos um povo pacífico, que gostamos de futebol, praia e cerveja e que não julgamos ninguém, que todos são bem recebidos, que todos são felizes etc.

Aquela expressão tem seus complementos similares: “cada qual deve saber o seu lugar”; "um lugar para cada coisa, cada coisa em seu lugar"; "cada macaco no seu galho". Em todos os casos, temos uma assunção explícita de uma questão hierárquica e autoritária, mas que buscamos velar. Na verdade, a gente parece fazer questão de excluir o que não gostamos e que sabemos que existe e é real. Daí porque é embaraçoso lidar com esse dito: porque, ao ser pronunciado, ele nos revela como é natural que cada um tenha seu lugar em nossa sociedade, a tal ponto que nem se deveria dizer em voz alta o que todos já sabem. Como se essa situação fosse inquestionável: "eu tenho realmente que lembrar a esse sujeito que ele está falando comigo?", pois é "óbvio" que existem os fortes e os fracos no Brasil, então por que anunciar isso? Eis o que é incomodo, embaraçoso de se assumir: "claro está que o 'sabe com quem está falando?' denuncia em níveis cotidianos essa ojeriza à discórdia e à crise, traço que vejo como básico num sistema social extremamente preocupado com 'cada qual no seu lugar', isto é, com hierarquia e com a autoridade" (DAMATTA, 1997, p. 184).

Assim, mantemos nosso sistema de exclusão, de hierarquia, de autoritarismo e achamos embaraçoso falar sobre isso. Quando alguém força outra pessoa a anunciar aquela frase, estamos fazendo algo indesejável: é mesmo preciso dizer isso? Você não conhece como é o

\footnotetext{
${ }^{5}$ Buscamos esconder nosso sistema autoritário: “o mundo da rua usa o 'sabe com quem está falando?', mas nós decidimos não integrar o rito no modo doce, gostoso e não-rotinizado com que preferimos tomar consciência do nosso universo social. Desse modo, o 'sabe com quem está falando?' não é levado a sério em nossas reflexões (eruditas ou de senso comum), do mesmo modo que ainda não deu letra de samba” (DAMATTA, 1997, p. 183).
} 
sistema (político/ético/social brasileiro)? Trata-se de um rito de autoridade que insiste em se repetir e que insiste em ser mascarado, pois o que é natural entre nossos conterrâneos é a intimidade, o favor e o respeito como valores - algo que parece natural na hierarquia brasileira. Não se fala com um Senhor como se fosse um igual: deve-se falar como se estivesse pedindo um favor,

pois essa fórmula só deve ou pode operar funcionalmente numa sociedade de gentes, de pessoas que se lavam, de brancos, de boa gente, de medalhões [muito bem descrito por Machado de Assis no conto Teoria do medalhão em 1882], em oposição às gentinhas, ao zé-povinho, à arraia-miúda, à gentalha, à massa; numa palavra, aos impuros em geral (DAMATTA, 1997, p. 204).

Não é isso que dá condição de possibilidade à ideia de eugenia?

Da mesma forma, seria muito estranho que alguém questionasse a autoridade de um médico, de um advogado, de um político etc. no Brasil para enviar alguém ao Hospital Colônia - trata-se de um sistema hierárquico em que se pode exercer seu poder de exclusão. O que é naturalizado em nossa sociedade é que todos brasileiros saibam qual é "seu lugar", sendo desnecessário que se anuncie "sabe com que está falando?" - mas algo que é repetido sempre que "necessário": quando alguém coloca em questão o seu "lugar"!

Foi exatamente isso que um dos médicos que visitou Barbacena nos denunciou. Relembremos a passagem: "é permitido andar nu e comer bosta, mas é proibido o protesto qualquer que seja a sua forma" (ABEX, 2013, p. 200). Eis o destino "cômico" de uma sociedade autoritária. Quer dizer, não há um sistema igualitário jurídico senão em papel. No dia-a-dia, o que vale é "quem está falando", quem é a autoridade, numa hierarquia de valores entre pessoas. Eis a lógica:

como diz o velho ditado brasileiro: 'Aos inimigos a lei, aos amigos, tudo!' Ou seja, para os adversários, basta o tratamento generalizante e impessoal da lei, a eles aplicada sem nenhuma distinção e consideração, isto é, sem atenuantes. Mas, para os amigos, tudo, inclusive a possibilidade de tornar a lei irracional por não se aplicar evidentemente a eles (DAMATTA, 1997, p. 217).

Isto é, é como se algumas pessoas devessem ser tratadas diferentemente por ser "alguém" superior socialmente, quebrando a igualdade perante a lei.

Tendo isso em vista, DaMatta propõe diferenciar indivíduo de pessoa. O primeiro é aquele que está sujeito às leis; o segundo é aquele que tem um tratamento pessoal, mais "familiar", em que o caso é esquecido ou, ao menos, não tão grave. "Em outras palavras, o 'sabe com quem está falando?' permite estabelecer a pessoa onde antes só havia um indivíduo" (DAMATTA, 1997, p. 220). O que DaMatta propõe é uma diferença entre sociedades em que 
as leis são igualitárias, portanto, de indivíduos ${ }^{6}$, e uma sociedade em que as leis seguem um caminho patriarcal, hierárquico e autoritário ( $c f$. DAMATTA, 1997, pp. 225-226).

Mesmo que Roberto DaMatta não mencione as barbáries que aqui se trouxe à tona do Hospital Colônia, esse tipo de reflexão mostra ou tenta mostrar porque as pessoas, no caso, os funcionários do tal Hospital, seguem as regras sem questionar - porque entram num tipo de sistema patriarcal em que há uma rígida hierarquia. Justificável? Penso que não. Mas temos ao menos um esboço de uma explicação do inexplicável. É como se, no sistema autoritário, todos tivessem um destino cômico: de cumprir o que foi estabelecido para se "purificar" diante da lei. Qualquer ameaça de contradizer esse destino é punida - com exclusão.

\section{REFERÊNCIAS BIBLIOGRÁFICAS}

AGAMBEN, Giorgio. O que resta de Auschwitz. Trad. Selvino J. Assmann. São Paulo: Boitmpo, 2008.

ARBEX, Daniela. Holocausto brasileiro - Genocídio: 60 mil mortos no maior hospício do Brasil. São Paulo: Geração Editorial, 2013.

ARENDT, Hannah. Eichmann à Jésuralem. Trad. Anne Guérin. Paris: Gallimard, 1997.

AUSTIN, John Langshaw. How to do things with words. London: Oxford University Press, 1962.

CHAUI, Marilena. Manifestações ideológicas do autoritarismo brasileiro. Belo Horizonte: Autêntica Editora; São Paulo: Editora Fundação Perseu Abramo, 2013.

DAMATTA, Roberto. Carnavais, malandros e heróis - para uma sociologia do dilema brasileiro. Rio de Janeiro: Rocco, 1997.

HOLANDA, Sérgio Buarque. Raízes do Brasil. São Paulo: Companhia das Letras, 1995.

LEVI, Primo. A assimetria e a vida - artigos e ensaios (1955-1987). Trad. Ivone Benedetti. São Paulo: Editora Unesp, 2016.

SCHWARZ, Roberto. Ao vencedor as batatas. São Paulo: Duas Cidades, 2000.

\footnotetext{
${ }^{6}$ Daí o sentido negativo dado ao indivíduo na sociedade brasileira: "individualizar significa, antes de tudo, desvincular-se dos segmentos tradicionais como a casa, a família, o eixo das relações pessoais como meios de ligação com a totalidade. Trata-se de buscar uma ligação com o Estado, por meio de associações voluntárias como o sindicato, o partido político e os órgãos de representação de classe. Mas para tanto é preciso abrir mão dos direitos substantivamente dados pelo sangue, pela filiação, pelo casamento, pela amizade e pelo compadrio" (DAMATTA, 1997, pp. 231-232).
} 